\title{
Parathyroid Disorders
}


Frontiers of Hormone Research

\author{
Vol. 51 \\ Series Editor \\ Ezio Ghigo Turin
}

Co-Editor

Federica Guaraldi Bologna 


\section{Parathyroid Disorders}

\section{Focusing on Unmet Needs}

Volume Editor

Maria Luisa Brandi Florence

12 figures, 5 in color, and 14 tables, 2019

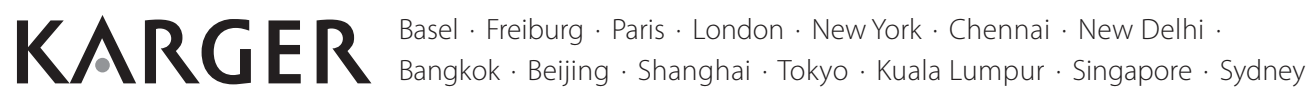


Frontiers of Hormone Research

Founded 1972 by Tj.B. van Wimersma Greidanus, Utrecht

Continued by Ashley B. Grossman, Oxford (1996-2013)

\author{
Maria Luisa Brandi, MD, PhD \\ Bone Metabolic Diseases Unit, Department of \\ Surgery and Translational Medicine \\ University of Florence \\ Florence (Italy)
}

Library of Congress Cataloging-in-Publication Data

Names: Brandi, M. L. (Maria Luisa), editor.

Title: Parathyroid disorders : focusing on unmet needs / volume editor, Maria

Luisa Brandi.

Other titles: Frontiers of hormone research ; v. 51. 0301-3073

Description: Basel ; New York : Karger, 2019. | Series: Frontiers of hormone

research, ISSN 0301-3073; vol. 51 | Includes bibliographical references

and indexes.

Identifiers: LCCN 2018037624| ISBN 9783318064087 (hard cover : alk. paper) |

ISBN 9783318064094 (e-book)

Subjects: | MESH: Hyperparathyroidism | Hypoparathyroidism | Hypercalcemia

Classification: LCC RC656.3 | NLM WK 300 | DDC 616.4/45--dc23 LC record available at

https://lccn.loc.gov/2018037624

Bibliographic Indices. This publication is listed in bibliographic services, including Current Contents ${ }^{\circledR}$ and PubMed/MEDLINE.

Disclaimer. The statements, opinions and data contained in this publication are solely those of the individual authors and contributors and not of the publisher and the editor(s). The appearance of advertisements in the book is not a warranty, endorsement, or approval of the products or services advertised or of their effectiveness, quality or safety. The publisher and the editor(s) disclaim responsibility for any injury to persons or property resulting from any ideas, methods, instructions or products referred to in the content or advertisements.

Drug Dosage. The authors and the publisher have exerted every effort to ensure that drug selection and dosage set forth in this text are in accord with current recommendations and practice at the time of publication. However, in view of ongoing research, changes in government regulations, and the constant flow of information relating to drug therapy and drug reactions, the reader is urged to check the package insert for each drug for any change in indications and dosage and for added warnings and precautions. This is particularly important when the recommended agent is a new and/or infrequently employed drug.

All rights reserved. No part of this publication may be translated into other languages, reproduced or utilized in any form or by any means electronic or mechanical, including photocopying, recording, microcopying, or by any information storage and retrieval system, without permission in writing from the publisher.

(c) Copyright 2019 by S. Karger AG, P.O. Box, CH-4009 Basel (Switzerland)

www.karger.com

Printed on acid-free and non-aging paper (ISO 9706)

ISSN 0301-3073

e-ISSN 1662-3762

ISBN 978-3-318-06408-7

e-ISBN 978-3-318-06409-4 


\section{Contents}

VII Preface

Brandi, M.L. (Florence)

1 Primary Hyperparathyroidism

Masi, L. (Florence)

13 Asymptomatic Primary Hyperparathyroidism

Clarke, B.L. (Rochester, MN)

23 Normocalcemic Hyperparathyroidism

Corbetta, S. (Milan)

40 Familial and Hereditary Forms of Primary Hyperparathyroidism

Cetani, F.; Saponaro, F.; Borsari, S.; Marcocci, C. (Pisa)

52 Familial Hypocalciuric Hypercalcemia and Neonatal Severe Hyperparathyroidism

Vannucci, L.; Brandi, M.L. (Florence)

63 Parathyroid Carcinoma

Cetani, F.; Pardi, E.; Marcocci, C. (Pisa)

77 Nonparathyroid Hypercalcemia

Goltzman, D. (Montreal, QC)

91 Secondary and Tertiary Hyperparathyroidism

Messa, P.; Alfieri, C.M. (Milan)

109 Hypoparathyroidism

Hakami, Y.; Khan, A. (Hamilton, ON)

127 Classification of Hypoparathyroid Disorders

Cianferotti, L. (Florence)

139 Clinical Presentation of Hypoparathyroidism

Giusti, F.; Brandi, M.L. (Florence)

147 Inactivating PTH/PTHrP Signaling Disorders

Mantovani, G.; Elli, F.M. (Milan)

160 Conventional Treatment of Hypoparathyroidism

Marcucci, G.; Brandi, M.L. (Florence) 
165 A New Era for Chronic Management of Hypoparathyroidism: Parathyroid Hormone Peptides

Marcucci, G.; Brandi, M.L. (Florence)

172 Author Index

173 Subject Index 


\section{Preface}

Disorders of the function of parathyroid glands most commonly present with abnormalities of calcium homeostasis. The area of mineral metabolism was not receiving the same attention as diseases affecting other endocrine glands. This was due in part to the lack of targeted medical therapies both in hyperparathyroidism and in hypoparathyroidism. However, recent developments in the medical therapy of hypoparathyroidism has created a renewed interest in parathyroid disorders overall.

Clinical practice guidelines, which describe the consensus of experts in the field, are available for the management of hyperparathyroidism and hypoparathyroidism. Recognition of the need for more research to optimize care in parathyroid disorders has emerged in recent publications.

This book puts together the experiences of specialists in the field, as the demands placed upon a clinician's time are both unrelenting and enormous. As a busy specialist in this field, I believe there is a genuine need for an up-to-date evidence-based overview that is practically oriented. The aim of this book is to serve as a practical guide to the clinical management of common parathyroid conditions.

The book will be relevant to specialists, general practitioners, undergraduates, postgraduates, and clinical nurse specialists. I am extremely grateful to the contributors who, as experts in their individual areas, have provided authority, experience, and invaluable insight. Finally, we would like to thank Karger for having the trust, determination, and encouragement to carry this project to fruition.

Maria Luisa Brandi, Florence 
